\title{
THE ROLE OF E-COMMERCE IN THE WORLD ECONOMY
}

\author{
Matniyazov Rakhim', Asraev Umar², Ruziev Abdumalik ${ }^{3}$ \\ ${ }^{1}$ Senior lecturer, Department of Electronic Commerce and Digital Economics, Tashkent Financial Institute, Uzbekistan. \\ ${ }^{2}$ Senior lecturer, Department of Electronic Commerce and Digital Economics, Tashkent Financial Institute, Uzbekistan. \\ ${ }^{3}$ Senior lecturer, Department of Electronic Commerce and Digital Economics, Tashkent Financial Institute, Uzbekistan. \\ E-mail address: ruziyev56@gmail.com
}

\section{ABSTRACT}

Keywords:

\section{Introduction.}

The global community's need for information technology (IT) to achieve the intended development and prosperity is growing rapidly. The growth of economic growth, the improvement of living standards of the world's population is the result of the integration of information technology into our daily lives. World experience shows that the free flow of information accelerates the transition to a market economy and increases social welfare. The rapid development of information technology is reflected in the economy. The success of today's economy, especially in the field of entrepreneurship, is based on the high level of development and effective use of various segments of information technology. Of course, the Uzbek economy is no exception. A clear example is the steady development of a number of segments of information technology, such as data transmission networks, information Internet resources and electronic document exchange between them, business and commerce. For Uzbekistan, the development of information technology plays an important role in ensuring new economic ties. However, this process will take place only if there is a certain level of information readiness of the society, which will arise as a result of increasing educational standards in the field of information technology, modernization of national telecommunications networks, the formation of the legal framework. As a result of the gradual development of the Uzbek economy, new principles of doing business, especially e-commerce, have become increasingly important. To date, every Internet user has tried to understand the meaning of the word e-commerce. The U.S. market, which has yet to build a long history of such activity, generates an average of $\$ 1.5-2$ trillion a year. U.S. dollars will be converted. The term "ecommerce" includes technologies such as EDI (Electronic Data Interchange), e-mail, Internet, intranet (exchange of information within the company) and extranet (exchange of information with the outside world). In turn, the e-commerce system is divided into three classes: Ecommerce, also known as electronic commerce or internet commerce, refers to the buying and selling of goods or services using the internet, and the transfer of money and data to execute these transactions. Ecommerce is often used to refer to the sale of physical products online, but it can also describe any kind of commercial transaction that is facilitated through the internet.

Whereas e-business refers to all aspects of operating an online business, ecommerce refers specifically to the transaction of goods and services.

The history of ecommerce begins with the first ever online sale: on the August 11, 1994 a man sold a CD by the band Sting to his friend through his website NetMarket, an American retail platform. This is the first example of a consumer purchasing a product from a business through the World Wide Web-or "ecommerce" as we commonly know it today. 
Since then, ecommerce has evolved to make products easier to discover and purchase through online retailers and marketplaces. Independent freelancers, small businesses, and large corporations have all benefited from ecommerce, which enables them to sell their goods and services at a scale that was not possible with traditional offline retail.

E-commerce has its advantages and disadvantages:

- Increased access to information in international transactions;

- Production and sales periods are shortened;

- The cost of information exchange is reduced through the use of cheap means of communication.

The company has an open relationship with consumers through the effective use of information technology, providing partners and customers with quick information about products and services, alternative ways of selling, for example, opening e-shops on commercial sites and allows you to create.Uzbekistan is in the process of developing e-commerce. Today, government agencies in Uzbekistan follow the following principles, which are widely used in the development of e-commerce in the world.

- The corporate sector should play an active role in the development of e-commerce;

- Various unreasonable restrictions on ecommerce by government agencies should not be allowed;

- Public authorities can intervene in the ecommerce process in order to support the sector and improve the legal framework;

- In developing e-commerce management measures, public authorities should take into account the specifics of the Internet;

- The e-commerce process should take place on a global scale, independent of administrativeterritorial divisions and state borders.

As a result of economic development, Uzbekistan is strengthening its position in the international economic system. This, in turn, necessitates the improvement of e-commerce infrastructure, ensuring its emergence as a strong competitor in the global market. In view of the above, a number of significant steps have been taken to improve the legal framework for e-commerce. Law of the Republic of Uzbekistan "On Electronic Commerce" N613-II of April 29, 2004, Resolution of the Cabinet of Ministers of November 30, 2007 №21 "On Development of Electronic Commerce" Improving the payment system in the country. In addition, in order to develop e-commerce in the country, the project "Ekarmon" has been developed and is being effectively implemented.

\section{NOW LET'S LOOK AT THE WORK DONE IN OTHER COUNTRIES IN THIS DIRECTION}

For example, in Kazakhstan, from January 1, 2018, the new Tax Code provides for the provision of tax benefits for entrepreneurs operating in online stores or online sites. In particular, legal entities are exempt from corporate income tax, and individual entrepreneurs are exempt from income tax, but three mandatory conditions must be met: making non-cash payments for goods; concluding a contract with the buyer online; the entrepreneur must have his own delivery service or enter into a contract with a person engaged in transportation, shipment and delivery of goods. An entrepreneur can be exempted from this type of tax only if the income from e-commerce with individuals is $90 \%$ of the gross annual income of the business entity. In Belarus, a special procedure for taxation of ecommerce is partially envisaged. From January 1, 2018, the Tax Code came into force, which provides for the collection of VAT on electronic services provided by foreign companies. In addition, businesses engaged in e-commerce can apply a simplified system of taxation. Their rates are:

$5 \%$ - for VAT-paying organizations and individual entrepreneurs;

$3 \%$ - for VAT-paying organizations and individual entrepreneurs.

On January 1, 2017, a law came into force in Azerbaijan, which provides for the taxation of e- 
commerce, in particular, the value added tax (VAT - 18\%). These measures were taken to protect local entrepreneurs, ie if the abovementioned services are provided by non-residents in the territory of the country for citizens of Azerbaijan, VAT will be collected from buyers. Based on this, it can be said that one of the key elements of the rapid development of e-commerce is the tax benefits provided by the state. The Resolution of the President of the Republic of Uzbekistan No. NECHI "On measures to accelerate the development of e-commerce" identifies the factors that stimulate the development of e-commerce. Including: Electronic checks, receipts, messages and other methods generated by information systems in the process of providing services by e-commerce participants in accordance with the legislation, allowing to identify the parties to transactions, are equated to receipts, coupons, tickets and other documents confirming payment for goods (services);

\section{PROBLEMS}

It should be noted that in addition to the development of e-commerce in Uzbekistan, there are a number of problems that hinder the development of this sector. Prompt and clear solution of these problems is one of the important requirements of today. Because the following issues are common in the world, and if they are not addressed properly, they can lead to serious crises in this area.The first is that the necessary infrastructure is still not sufficiently improved. Here are some examples:

- The number of providers directly connected to the global network of the Internet is limited, and as a result, the Internet is delivered to customers through the transfer from one provider to another, which is known to negatively affect the quality of service. 'shows the mystery.

- The quality of Internet services provided in the provinces is significantly worse than in the capital. As a result of insufficient conditions for a disconnected connection (ADCL modem), customers use a dial-up connection. This, in turn, leads to inadequate service quality. Second, the number of Internet users is such that it does not allow to create a large market for e-commerce (the number of Internet users in Uzbekistan is more than 2.5 million 4). It is true that in recent years a number of positive results have been achieved in this area, but it is growing only in certain regions (mainly the capital and some regional centers). In many areas, this is still a problem. It is well known that running an e-commerce business without having a sufficient market is detrimental to any entrepreneur. Third, there is a lack of a reliable system that allows individuals to make online payments from bank accounts. We can make payments from plastic cards issued by our banks only using special terminals, and in international practice, using plastic cards, through special modules installed to receive payment, directly on-line do Payments can be made at the mines. The main problem is that online banking services for individuals are not widespread in Uzbekistan. On-line banking allows bank customers to manage their accounts and make payments online or via mobile. SMS-banking offered by several banks is one-way and is intended only for receiving information about accounts and transaction history. This is one of the biggest obstacles to the development of ecommerce. Fourth, existing online stores lack a high level of professionalism. According to the Communications and Information Agency, as of 01.01.2008, there are 24 online stores in Uzbekistan. Sales of computer and electronic consumer goods - 8, gifts and flowers - 4, digital goods - 6, consumer and household goods - 3, books, music and the $\mathrm{CD}$ has 3 stores dedicated to selling movies. This allows websites to make 4 payments using plastic cards from the international payment system, using the 12-WM Transfer payment system. The remaining 7 stores will allow cashless payments once a written contract has been signed.

\section{Types of Ecommerce Models}

There are four main types of ecommerce models that can describe almost every transaction that takes place between consumers and businesses. 
1. Business to Consumer (B2C): When a business sells a good or service to an individual consumer (e.g. You buy a pair of shoes from an online retailer).

\section{Business to Business (B2B):}

When a business sells a good or service to another business (e.g. A business sells software-as-aservice for other businesses to use)

\section{Consumer to Consumer (C2C):}

When a consumer sells a good or service to another consumer (e.g. You sell your old furniture on eBay to another consumer).

\section{Consumer to Business (C2B):}

When a consumer sells their own products or services to a business or organization (e.g. An influencer offers exposure to their online audience in exchange for a fee, or a photographer licenses their photo for a business to use).

\section{Examples of Ecommerce}

Ecommerce can take on a variety of forms involving different transactional relationships between businesses and consumers, as well as different objects being exchanged as part of these transactions.

\section{Retail:}

The sale of a product by a business directly to a customer without any intermediary.

\section{Wholesale:}

The sale of products in bulk, often to a retailer that then sells them directly to consumers.

\section{Dropshipping:}

The sale of a product, which is manufactured and shipped to the consumer by a third party.

\section{Crowdfunding:}

The collection of money from consumers in advance of a product being available in order to raise the startup capital necessary to bring it to market.

\section{Subscription:}

The automatic recurring purchase of a product or service on a regular basis until the subscriber chooses

to

cancel.

\section{Physical products:}

Any tangible good that requires inventory to be replenished and orders to be physically shipped to customers as sales are made.

\section{Digital products:}

Downloadable digital goods, templates, and courses, or media that must be purchased for consumption or licensed for use.

\section{Services:}

A skill or set of skills provided in exchange for compensation. The service provider's time can be purchased for a fee.

\section{Suggestions and Conclusions}

We suggest the following as the main directions in solving the above problems: It is necessary to deepen scientific research in the field of ecommerce. Research, writing articles, creating specialized Internet resources, organizing regular forums and conferences, taking into account not only the technical, but also economic and legal features of e-commerce in training, one of the main problems is the lack of qualified personnel. Developing competition in the field of telecommunications services. This will lead to an increase in the quality of services, lower prices and the creation of certain Internet audiences for e-commerce. Ensuring that the right legal environment for investment in the ICT sector is always in place. Creating self-management and experience sharing systems Development of elearning system Ensuring the dissemination of information technology throughout Uzbekistan. The introduction of information technology not only in regional centers, but also in remote villages will lead to a significant increase in the volume of e-commerce. Effective introduction of online banking system throughout the country. 
This will allow entrepreneurs engaged in wholesale and retail trade to freely trade their goods and services online. At the same time, it will lead to significant changes in other areas of the banking sector. We suggest the following as the main directions in solving the above problems:

\section{References}

[1] Jumaniyazova M.Yu, Ilxamova Yo.S., Azizova M.I., Dgamalova G.C. Ecommerce - in the economy of the world and Uzbekistan. International Journal of Advanced Science and Technology. 2019.11.14 49-54pp.

[2] Jumaniyzova Muqaddas, Mannanova Shakhida, Avalova Gulshod. Wold experience of digital platform development trends. Journal of Critical Reviews.Vol 7, Issue $\quad 9, \quad 2020 . \quad$ DOI: http://dx.doi.org/10.31838/jcr.07.09.59

[3] Djumaniyazova M.Yu. Technology of use of digital platform in management of agricultural economy of Uzbekistan. The International Conference Proceedings on "Investments and entrepreneurship: challenges and prospects". May 7, 2019.

[4] Ayupov R.X., Djumaniyazova M.Yu. Digital transformation in the rural economy of the Republic of Uzbekistan. International Journal of Humanitarian and Natural Sciences »2019 №5, pp.87-91. Electronic resource [https://cyberleninka.ru/article/n/tsifrovaya -transformatsiya-v-selskom-hozyaystverespubliki-uzbekistan]. 